\title{
PENERAPAN PRINSIP-PRINSIP HYGIENE SANITASI MAKANAN DI INSTALASI GIZI RUMAH SAKIT ISLAM SITI AISYAH MADIUN TAHUN 2015
}

\author{
Choirul Annisak, Moch.Yulianto, Hurip Jayadi
}

\begin{abstract}
Abstrak
Pengelolaan makanan di Rumah Sakit Islam Siti Aisyah Madiun perlu dilakukan pengawasan khusus diantara kegiatan di rumah sakit, karena pengelolaan makanan merupakan pelayanan dari rumah sakit dalam upaya penyembuhan dan pemulihan pada pasien. Untuk itu perlu dilakukan observasi tentang penerapan prinsip hygiene sanitasi makanan dan pengetahuan penjamah makanannya.

Penelitian ini merupakan penelitian deskriptif yang bertujuan untuk menggambarkan pengetahuan penjamah makanan dalam menerapkan prinsip-prinsip hygiene sanitasi makanan dan minuman di instalasi gizi Rumah Sakit Islam Siti Aisyah Madiun. Variabel bebas dalam penelitian ini adalah pengetahuan penjamah makanan sedangkan variabel terikatnya adalah prinsi-prinsip hygiene sanitasi makanan. Analisa data menggunakan editing dan rekapitulasi sedangkan penyajian dalam betuk tabel dan grafik.

Hasil pengetahuan penjamah makanan di instalasi gizi Rumah Sakit Islam Siti Aisyah Madiun tentang 6 prinsip hygiene sanitasi makanan pada umumnya baik. Kegiatan penerapan prinsip hygiene sanitasi makanan di instalasi gizi Rumah Sakit Islam Siti Aisyah Madiun pada umumnya baik. Pada umumnya penjamah makanan di instalasi gizi Rumah Sakit Islam Siti Aisyah Madiun memiliki pengetahuan yang baik, dimana pengetahuan mereka mendukung kinerja dalam menerapkan prinsip hygiene sanitasi makanan.

Kesimpulan dari penelitian ini adalah penjamah makanan di Instalasi Gizi RSI Siti Aisyah Madiun memiliki pengetahuan dan penerapan yang baik. Untuk lebih meningkatan maka penulis menyarankan untuk melakukan pelatihan mauun penyuluhan kepada penjamah makanan tentang hygiene sanitasi makanan dan memperbaiki beberapa fasilitas yang belum memenuhi syarat kesehatan.
\end{abstract}

Kata Kunci : Penerapan Prinsip Hygiene Sanitasi Makanan

\section{PENDAHULUAN}

Penyehatan makanan di rumah sakit juga memiliki tujuan untuk menyediakan makanan yang berkualitas baik dan aman bagi pasien dan konsumen serta terwujudnya perilaku kerja yang sehat dan higienis dalam penanganan makanan, sehingga pasien dan konsumen lainnya terhindar dari resiko penularan penyakit atau gangguan kesehatan dan keracunan makanan.

Upaya penyehatan makanan di rumah sakit harus dilakukan untuk menghasilkan makanan yang sehat, baik dan terhindar dari Food Born Disease. Hygiene sanitasi makanan merupakan hal penting mengingat bahwa makanan yang disajikan kepada pasien harus terjaga dan terjamin kualitasnya demi keamanan pangan. Sanitasi makanan di rumah sakit ditujukan pada semua tingkatan, sejak makanan mulai dibeli, disimpan, diolah dan disajikan. Sedangkan hygiene makanan dilakukan kepada kebersihan penjamah makanan. Karena tenaga penjamah makanan mempunyai peran yang tidak kecil terhadap kemungkinan terjadinya kontaminasi makanan yang disajikan.
Upaya hygiene sanitasi makanan tersebut dalam pelaksanaannya disebut dengan 6 prinsip upaya yang meliputi pemilihan bahan makanan, penyimpanan bahan makanan, pengolahan makanan, penyimpanan makanan jadi, pengangkutan dna penyajian makanan. Prinsip hygiene sanitasi makanan dan minuman adalah pengendalian terhadap fisik, kimia dan mikrobiologi pada makanan. Prinsip-prinsip dasar sanitasi penyelenggaraan makanan di rumah sakit pada dasarnya tidak berbeda dengan tempat - tempat penyelenggaraan makanan lain.

Rumah Sakit Islam Siti Aisyah Madiun terletak di Jalan Mayjen Sungkono Nomor 38 Kota Madiun, Kelurahan Nambangan Lor Kecamatan Mangunharjo Kota Madiun, yang merupakan rumah sakit publik dengan tipe C. Pelayanan makanan dan minuman untuk pasien dilakukan pengolahan sendiri di dapur rumah sakit. Dibagian instalasi gizi rumah sakit memiliki pegawai sejumlah 18 karyawan yang terdiri dari tenaga pengolah makanan 10 orang, pendistribusian 6 orang dan ahli gizi 2 orang.

Apabila dicermati setelah melakukan observasi awal gambaran pengelolaan 
makanan di unit gizi rumah sakit Islam Aisyah Madiun tersebut menunjukkan belum diterapkannya prinsip-prinsip hygiene sanitasimakananminuman.

Rendahnya upaya hygiene sanitasi makanan ini menurut beberapa ahli disebabkan oleh komitmen manajemen khususnya dalam hal standardisasi layanan, kurangnya sarana, ketersediaan dana dan biaya, serta perilaku penjamah makanan (WHO, 1996)

Tujuan Penelitian: Mengetahui tingkat pengetahuan tentang prinsip-prinsip hygiene sanitasi makanan menjadi penyebab kurangnya penerapan prinsip-prinsip hygiene sanitasi makanan di instalasi gizi Rumah Sakit Islam Siti Aisyah Madiun, yang dirinci menjadi:

1. Mengobservasi bagaimana pengetahuan masing-masing kelompok kegiatan prinsip hygiene sanitasi makanan di instalasi gizi Rumah Sakit Islam Siti Aisyah Madiun.

2. Mengobservasi bagaimana penerapan masing-masing kelompok kegiatan prinsip hygiene sanitasi makanan di instalasi gizi Rumah Sakit Islam Siti Aisyah Madiun.

3. Mengukur hubungan antara pengetahuan dan penerapan berdasarkan kategori baik-baik, baik-cukup, cukup-baik dan cukup-cukup di instalasi gizi Rumah Sakit Islam Siti Aisyah Madiun.

\section{METODE PENELITIAN}

Penelitian ini bersifat deskriptif dengan jumlah populasi adalah 18 orang terdiri dari 2 orang ahli gizi, 10 orang pengolah makanan dan 6 orang pendistribusian makanan. Sampel sebanyak 16 orang yaitu pada pengolah makana dan pendistribusian makanan.

Pengumpulan data dilakukan dengan melalui kuesioner tentang pengetahuan penjamah makanan tentang hygiene sanitasi makanan, lembar observasi untuk observasi penerapan prinsip hygiene sanitasi makanan serta melalui wawancara. Analisa data dilakukan dengan menggunakan tabel distribusi dan frekuensi dengan menghitung persentase yaitu dengan cara, editing, coding, skoring, dan tabulating.

\section{HASIL DAN PEMBAHASAN}

1. Karakteristik responden

Responden berjumlah 16 orang yang terdiri dari 10 orang bagian pengolah makanan dan 6 orang pada bagian distribusi makanan. Karakteristik responden mencakup usia, jenis kelamin, pendidikan dan status kepegawaian. Berikut akan disampaikan karakteristik responden tersebut :

Tabel 1 Karakteristik Penjamah Makanan di Instalasi Gizi RSI Madiun

\begin{tabular}{cccc}
\hline No. & Karakteristik & Frekuensi & Persentase (\%) \\
\hline 1 & Usia & 4 & 25 \\
\hline & $25-35$ & 7 & 43,75 \\
\hline $36-46$ & 5 & 31,25 \\
\hline 2 & $47-57$ & & 37,5 \\
\hline & Jenis Kelamin & 6 & 62,5 \\
\hline Laki-laki & 10 & 12,5 \\
\hline 3 & Perempuan & & 87,5 \\
\hline & Pendidikan & 2 & \\
\hline 4 & Tamat SMP & 14 & 68,75 \\
\hline & Tamat SMA & & 31,25 \\
\hline
\end{tabular}

Tenaga penjamah makanan di Instalasi Gizi RSI Madiun dibagi menjadi 2 bagian yaitu tenaga pengolah makanan dan tenaga distribusi. Pada bagian pengolah makanan terdapat 10 orang penjamah
2. Pengukuran pengetahuan makanan sedangkan di bagian distribusi terdapat 6 orang. Kuesioner dibagikan kepada 16 orang tersebut sesuai dengan tugas dan tanggung jawab masingmasing. 
Tabel 2 Hasil Pengetahuan Tenaga Pengolah MakananTentang Prinsip Hygiene Sanitasi Makanan di Instalasi Gizi RSI Siti Aisyah Madiun

\begin{tabular}{|c|l|c|c|c|c|}
\hline \multirow{2}{*}{ No. } & \multirow{2}{*}{$\begin{array}{c}\text { Prinsip Hygiene Sanitasi } \\
\text { Makanan }\end{array}$} & \multicolumn{3}{|c|}{ Baik } & \multicolumn{2}{c|}{ Cukup } \\
\cline { 3 - 6 } & & Frekuensi & $\begin{array}{c}\text { Persentase } \\
(\mathbf{\%})\end{array}$ & Frekuensi & $\begin{array}{c}\text { Persentas } \\
\text { e (\%) }\end{array}$ \\
\cline { 3 - 6 } & & 8 & 80 & 2 & 20 \\
\hline 1 & Pemilihan bahan makanan & 9 & 90 & 1 & 10 \\
\hline 2 & Penyimpanan bahan makanan & 7 & 70 & 3 & 30 \\
\hline 3 & Pengolahan makanan & 3 & 30 & 7 & 70 \\
\hline 4 & Penyimpanan makanan & 3 & 50 & 3 & 50 \\
\hline 5 & Pengangkutan makanan & 6 & 60 & 4 & 40 \\
\hline 6 & Penyajian makanan & \multicolumn{3}{|c|}{} \\
\hline
\end{tabular}

Secara umum pengetahuan penjamah makanan tentang prisip-prinsip hygiene sanitasi makanan di instalasi gizi RSI Siti Aisyah Madiun adalah baik. Hal ini bisa saja dipengaruhi oleh pendidikan penjamah makanan yanag rata-rata berpendidikan terakhir adalah SMA atau sederajat yaitu sebesar $87,5 \%$ atau 14 orang. Tingkat pendidikan seseorang akan berpengaruh dalam memberi respon terhadap sesuatu yang datang dari luar. Orang yang berpendidikan tinggi akan memberi respon

3. Observasi Penerapan Prinsip Hygiene Sanitasi Makanan Observasi dilakukan kepada seluruh penjamah makanan di yang lebih rasional terhadap informasi yang datang, akan berpikir sejauh mana keuntungan yang mungkin akan mereka peroleh dari gagasan tersebut. Namun pada beberapa prinsip hygiene sanitasi makanan penjamah makanan memiliki pengetahuan cukup yaitu pada penyimpanan makanan, penyajian makanan, pengangkutan makanan, pengolahan makanan, pemilihan bahan makanan dan penyimpanan bahan makanan.

instalasi gizi RSI Siti Aisyah Madiun yaitu pada 16 orang responden. Berikut disampaikan hasil observasi tersebut.

Tabel 3 Hasil Observasi Penerapan Prinsip Hygiene Sanitasi Makanan Tenaga Pengolah Makanan di Instalasi Gizi RSI Siti Aisyah Madiun

\begin{tabular}{|c|c|c|c|c|c|}
\hline \multirow{3}{*}{ No. } & \multirow{3}{*}{$\begin{array}{c}\text { Prinsip Hygiene Sanitasi } \\
\text { Makanan }\end{array}$} & \multicolumn{4}{|c|}{ Penerapan } \\
\hline & & \multicolumn{2}{|c|}{ Baik } & \multicolumn{2}{|c|}{ Cukup } \\
\hline & & Frekuensi & $\begin{array}{c}\text { Persentase } \\
(\%)\end{array}$ & Frekuensi & $\begin{array}{c}\text { Persentase } \\
(\%)\end{array}$ \\
\hline 1 & Pemilihan bahan makanan & 10 & 100 & 0 & 0 \\
\hline 2 & Penyimpanan bahan makanan & 2 & 20 & 8 & 80 \\
\hline 3 & Pengolahan makanan & 0 & 0 & 10 & 100 \\
\hline 4 & Penyimpanan makanan & 10 & 100 & 0 & 0 \\
\hline 5 & Pengangkutan makanan & 6 & 100 & 0 & 0 \\
\hline 6 & Penyajian makanan & 10 & 100 & 0 & 0 \\
\hline
\end{tabular}

Secara umum penerapan penjamah makanan pada prinsi-prinsip hygiene sanitasi makanan adalah baik. Hal ini terjadi karena didukung oleh pengetahuan penjamah makanan yang secara umum adalah baik. Karena penerapan prinsip hygiene sanitasi makanan ini penting untuk diketahui karena berperan besar sebagai faktor kunci keberhasilan usaha makanan. Selain itu pengtingnya penerapan prinsip hygiene sanitasi makanan karena jika tidak diterapkan dalam pengolahan makanan akan menjadikan makanan berbahaya, yaitu dapat mengakibatkan keracunan maupun food born deases.

Yang mempengaruhi seseorang menerapkan atau tidak menerapkan prinsip hygiene sanitasi makanan oleh penjamah makanan pertama adalah fasilitas yang disediakan. Fasilitas tersebut berpengaruh terhadap proses kerja dan makanan yang dihasilkan. Kedua adalah prosedur kerja yang megatur urutan dalam proses memasak makanan. Adanya sanksi kepada penjamah makanan yang melanggar prosedur kerja dapat mempengaruhi penjamah makanan dalam menerapkan prinsip hygiene sanitasi makanan. Adanya motivasi yang diberikan oleh manajer kepada penjamah makanan bisa mempengaruhi kinerja para penjamah makanan.

4. Hubungan Pengetahuan dan Penerapan Prinsip Hygiene Sanitasi Makanan Setelah mendapatkan hasil dari 
pengukuran pengetahuan dan hasil observasi penerapan prinsip kepada setiap penjamah makanan di intalasi gizi RSI Siti Aisyah Madiun, maka dilakukan pengolahan data lebih lanjut agar menjadi lebih bermakna, yakni dengan meghubungkan antara pegetahuan dan penerapan prinsip hygiene sanitasi makanan. Dalam hal ini dilakukan pengkategorian yaitu pengetahuan baik dan peneraan baik, pengetahuan baik tetapi penerapan cukup, pengetahuan cukup tetapi penerapan baik serta pengetahuan cukup dan penerapan cukup. Berikut akan disajikan hubungan dengan menggunakan kategori tersebut :

Tabel 4 Hasil Observasi Dan Penerapan Hygiene Sanitasi Makanan Tenaga Pengolah Makanan di Instalasi Gizi RSI Siti Aisyah Madiun

\begin{tabular}{|c|c|c|c|c|c|}
\hline \multirow[b]{2}{*}{ No. } & \multirow[b]{2}{*}{$\begin{array}{c}\text { Prinsip Hygiene Sanitasi } \\
\text { Makanan }\end{array}$} & \multicolumn{4}{|c|}{ Kategori Pengetahuan dan Penerapan } \\
\hline & & $\begin{array}{l}\text { Baik- } \\
\text { Baik }\end{array}$ & $\begin{array}{l}\text { Baik- } \\
\text { Cukup }\end{array}$ & $\begin{array}{l}\text { Cukup- } \\
\text { Baik }\end{array}$ & Cukup-Cukup \\
\hline 1 & Pemilihan bahan makanan & 8 & 0 & 2 & 0 \\
\hline 2 & Penyimpanan bahan makanan & 2 & 7 & 0 & 1 \\
\hline 3 & Pengolahan makanan & 0 & 7 & 0 & 3 \\
\hline 4 & Penyimpanan makanan & 3 & 0 & 7 & 0 \\
\hline 5 & Pengangkutan makanan & 2 & 0 & 4 & 0 \\
\hline 6 & Penyajian makanan & 6 & 0 & 4 & 0 \\
\hline
\end{tabular}

Penjamah makanan memiliki pengetahuan dan penerapan baik karena karena sumber daya manusia penjamah makanan yang didalamnya memiliki kemampuan yang baik, memiliki pengalaman yang cukup dalam mendapatkan bahan makanan yang berkualitas. Dan penjamah makanan yang memiliki pengetahaun dan penerapan cukup dikarenakan sumber daya manusia yang belum pernah mengikuti pelatihan maupun penyuluhan tenang hygiene sanitasi makanan.

Penjamah makanan yang memiliki pengetahuan baik tetapi penerapan cukup hal ini dimungkikan karena beberapa faktor diataranya adalah tingginya motivasi dari diri sendiri maupun dari pihak keluarga. Penjamah makanan yang memiliki pengetahuan baik tetapi penerapannya cukup hal ini terjadi karena adanya faktor yang mempermudah dan faktor pendukung sehingga memiliki pengetahuan yang baik, namun memiliki motivasi yang rendah sehingga mempengaruhi kinerja penjamah makanan tersebut.

\section{KESIMPULAN}

1. Pengetahuan penjamah makanan di instalasi gizi Rumah Sakit Islam Siti Aisyah Madiun tentang 6 prinsip hygiene sanitasi makanan pada umumnya baik yaitu dengan persentase sebesar $60 \%$ $80 \%$.

2. Kegiatan penerapan prinsip hygiene sanitasi makanan di instalasi gizi Rumah Sakit Islam Siti Aisyah Madiun pada umumnya baik dengan persentase sebesar $100 \%$.
3. Pada umumnya penjamah makanan di instalasi gizi Rumah Sakit Islam Siti Aisyah Madiun memiliki pengetahuan yang baik, dimana pengetahuan mereka mendukung kinerja dalam menerapkan prinsip hygiene sanitasi makanan.

\section{SARAN}

1. Memberikan sanksi yang telah disepakati bersama bagi penjamah makanan yang tidak melakukan sesuai dengan prosedur kerja dan prinsip hygiene sanitasi makanan.

2. Memasang prosedur kerja di tempat yang bisa dibaca oleh seluruh penjamah makanan.

3. Memberikan himbauan berupa poster atau leaflet tentang pentingnya menerapkan prinsip hygiene sanitasi makanan untuk menghasilkan makanan yang aman, sehat dan bersih.

4. Melakukan kontrol rutin pada makanan yang dihasilkan oleh penjamah makanan serta alat makan dan alat masak.

5. Penanggungjawab instalasi gizi memberikan motivasi kepada penjamah makanan agar menerapkan prinsip hygiene sanitasi makanan sehingga mnghasilkan makanan yang sehat, aman dan bersih.

6. Pihak menejemen atau yang bertanggungjawab pada instalasi gizi memenuhi sarana sanitasi yang belum lengkap seperti tempat cuci tangan dan memperbaiki tempat sampah dan sarana pembauang air limbah yang sesuai dengan syarat kesehatan. 
DAFTAR PUSTAKA

Anwar H, 1989. Sanitasi Makanan dan Minuman Pada Institusi Pendidikan Tenaga Sanitasi. Depkes RI, Proyek Pengembangan Pendidikan Tenaga Sanitasi Pusat.

Departemen Kesehatan RI, 1995. Pedoman Sanitasi Rumah Sakit di Indonesia. Jakarta, Direktorat Jendral PPM dan PLP dan Depkes RI.

\begin{tabular}{llr} 
& 1999 & .Kursus \\
\cline { 1 - 1 } Penyehatan & Makanan & Bagi
\end{tabular}

Makanan dan Minuman. Jakarta, Direktorat PLP, Ditjen PPM dan PLP.

1998. Penjamah Makanan dan Minuman Pedoman Pelatihan Untuk Pengusaha dan Penjamah Makanan. Jakarta, Direktorat Jendral PPM dan PLP dan Depkes RI.

Kementerian Kesehatan RI. Keputusan Menteri Kesehatan Republik Indonesia Nomor 1204/Menkes/SK/X/2004 Tentang Persyaratan Kesehatan Lingkungan Rumah Sakit.

. Peraturan Menteri Kesehatan Republik Indonesia Nomor 1096/Menkes/Per/VI/2011 Tentang Hygiene Sanitasi Jasa Boga

DR.Notoatmojo, Soekidjo, 1993. Metodologi Penelitian Kesehatan. Jakarta, PT.Rineka Cipta; Cetakan Pertama

Republik Indonesia. Undang-UndangRepublik Indonesia Nomor 40Tahun 2009 TentangRumahSakit.

Sanropie,Djasio,dkk, 1989. Komponen Sanitasi Rumah Sakit Untuk Institusi Pendidikan Tenaga Sanitasi. Jakarta, Departemen Kesehatan RI Proyek Pengembangan Pendidikan Tenaga Sanitasi Pusat Pendidikan Tanaga Kesehatan.
WHO, 1989. Health Surveilance and Management Procedure for $F$ ood-handling Personnel.

Adam, Yosvita Maria Nurmayasi Nurwyn,2011. Pengetahuan dan Perilaku Hygiene Tenaga Pengolah Makanan di Instalasi Gizi Rumah Sakit Umum Daerah Dr.Kanujoso Djatiwibowo Balikpapan. http://eprints.undip.ac.id/32574/1 386 Yosvita Maria G2C309009.p df, diakses pada tanggal 01 Pebruari 2014.

Sinaga,Mulverawaty,2010. Hygiene Dan Sanitasi Pengelolaan Makanan Di Instalasi Gizi Rumah Sakit Martha Friska Medan Tahun 2010. http://repository.usu.ac.id/b itsream/123456789/2393/4/chapt er\%2011.pdf, diakses pada tanggal 27 Januari 2014

Sukana,Bambang,Djarismawati dan Sugiharti,2004. Pengetahuan dan Perilaku Penjamah Makanan Tentang Sanitasi Pengolahan Makanan Pada Instalasi Gizi Rumah Sakit di Jakarta.http://ejournal.litbang.dep kes.go.id/index.php/MPK/article/vi ewFile/905/819, diakses pada tanggal 01 Pebruari 2014. 